\title{
A VOZ FEMININA DE UM CORPO NA EXPERIÊNCIA DO RITUAL
}

Renata Borges é bailarina, coreógrafa, poeta e mestranda em Literatura, Cultura e Contemporaneidade pelo Departamento de Letras da PUC - RJ. Atua no Grupo Bando e é pesquisadora convidada na NUDAFRO Cia de Dança da UFRJ. E-mail: rebaazevedo@gmail.com

Pés sobre o terreiro. O toque foi para Oxalá. Meu corpo feminino não tinha mais previsão. Os olhos fechavam. Corpo arcado. Joelhos que dobram. Não se pode ficar mais em pé. Calor. Não há o que fazer. Mas deixar. Ir. O corpo. O balanço. Transe. O santo montou em seu cavalo. O atabaque é outro limiar entre ir e ficar. A última coisa que era "eu" foi tomada tirando meus sapatos. Sem separação entre o material e o que é imaterial. Mas mora nas concretudes dentro de nós. Meus pés sobre o chão. Já não sabia mais. Sabia de menos. Sentia. O que me fica é sensação. De ser carregada. De ir para um lugar, mas achar que estava em outro. O outro lugar é o meu espaço de dentro. Do que me toma pela verdade. Como a água que pedia mais e mais na tentativa de me acalmar. No pedido ao "paizinho". Única palavra entendida. Até "acordar". Embora acordar seja o ato de incorporar. Corporificar o dentro. Falar meu nome. Entre choro e riso. Ouvir que é assim mesmo. Voltar para a festa dentro do meu corpo. Que já não era tão meu. Era outro. 